\title{
VIOLATION OF INFORMATION ECOLOGY IN MEDIA SPACE*
}

\author{
F.I. Sharkov ${ }^{1,2}$, V.V. Silkin ${ }^{1}$, \\ I.E. Abramova ${ }^{3}$, N.V. Kirillina ${ }^{1}$ \\ ${ }^{1}$ Russian Presidential Academy of National Economy and Public Administration \\ Prosp. Vernadskogo, 84, Moscow, 119571, Russia \\ ${ }^{2}$ Moscow State Institute of International Relations (MGIMO University) \\ Prosp. Vernadskogo, 76, Moscow, 119454, Russia \\ ${ }^{3}$ Rostov State Medical University \\ M. Gorky St., 11/43, Rostov-on-don, 344002, Russia \\ (e-mail: sharkov_felix@mail.ru; vv.silkin@migsu.ru; \\ www-abramova-achii@mail.ru; nata.kirillina@gmail.com)
}

\begin{abstract}
The extreme "pollution" of the global information space has a negative impact on the social well-being of the population for media space is a kind of social space covered by the media. It is necessary to create an effective system of legal protection and social guarantees so that any citizen can receive minimal social protection and be protected from the negative impact of the adverse ecology of the mass media. Not everyone who is experiencing intense exposure to the media is aware of its negative effects including "fatigue syndrome". To prevent it, D. Lewis proposes the following algorithm: use all information technologies of business and everyday communication; improve the methods of studying and processing data; set the right priorities for their analysis and use [26]. All media and actors that interact with them must master information culture, for which it is necessary to train specialists in the field of media ecology who are aware of the influence of media and social technologies on people's feelings, thoughts, values and behavior. So far, experts on media ecology do not have a sufficient theoretical basis for conducting sociological research and identifying how the media forces the audience to structure what it sees, hears and feels in a certain way. Today's media (especially electronic) can have a violent and undesirable effect - this is not only a psychological but also a philosophical, social and cultural problem that affects both children and adults. "Information anarchy" leads not only to moderate negative consequences but in some cases to "information ecocide" - destruction of traditional information and the media. Countering the contamination of the information environment should include the following steps: development of requirements for the content creation; monitoring of the collection, storage, processing and destruction of information; development of criteria for assessing the use of information. It is necessary to introduce a single rating system for information products, which will allow users to evaluate the quality of information sources according to the following criteria: purity of information; work on creating content; source coverage; quality (completeness) of information; sources of specific data sets; social-demographic characteristics of potential users.
\end{abstract}

Key words: environment; mass media; media space; media sociology; information ecology; informational hygiene; ecocide

* C F.I. Sharkov, V.V. Silkin, I.E. Abramova, N.V. Kirillina, 2018.

The article was submitted on 30.04.2018. 
Human environment includes natural, social and noosphere components: animal world is surrounded by solely natural environment; noosphere develops from natural sphere and biosphere; biosphere becomes a technosphere and functions under constant pressure, which has led to its collapse and violation of its life cycles, and, consequently, to the destruction of noosphere. "The utmost self-organization of a noosocietal system is possible with constant interaction between all its components. The necessity of unification of the mentioned subsystems into a single system is entailed by the fact that Nature has to confront not only numerous disasters (natural, political, social, etc.) caused not only by natural processes on the planet itself, but also by external to the Earth and hence more dangerous elements. Noosocietal system, in fact, is the mind of the planet, which unifies the organized beginning of self-organizing systems of the biosphere (including the human mind as its main component), information-crystallized (natural and technosphere), macrosocietal, and noosphere levels" [39. P. 78].

The possibility of self-preservation of ecological system, its components, including living systems, is limited to certain boundaries, beyond which the ability to reproduce and progress of both integrated living systems and their individual parts is lost. The stability of a living system manifests itself as an ability to resist the disturbing and destructive factors of internal and external environment and maintain one's qualities, and above all — adaptability. Most modern environmental challenges are determined by the interaction of society and nature for human activities disrupt the structure and relationship between existing ecological niches. "This new reality has not been yet recognized by all people as most of them do not take into account the dynamics of nature anthropogenic changes, confining themselves to the assessment of the today's status of nature that doesn't seem yet to inspire fear" [9. P. 186]. "Natural environment is influenced by many factors. Depending on negative anthropogenic impact on the environment we have to use different types of environmental audit. Subjects to such evaluation are various indicators of the hazard/safety of different activities and their results" [41. P. 71].

\section{DEFINITIONS OF SPACE, MEDIA AND MEDIA SPACE}

Before considering phenomena of media environment, it is necessary to define basic concepts of such analysis. Thus, "the old acoustic 'common sense' of space continued as spherical, multisensory and multidimensional space until the first age of alphabetic literacy, moreover, it provided the basis of considerable opposition to the new abstract visual space of the atomists" [22. P. 44]. The term 'media' refers to both primary and secondary (remote) mediators of social communications including electrical appliances, books, television and other elements that somehow affect communication and change the individual worldview. In recent years, the word 'media' has been used to name areas and content of media communications, such as social media, mass media, media content, etc.

In English-language publications the concept 'media space' has been used since the 1980s in the works of R. Stults and S. Harrison for "electronic environment in which groups of people can work together even if they are not present in the same place at 
the same time" [20; 45]. Some authors believe that the concept 'media space' was first used in sociology in 1990 by A. Appadurai [5]. Later, based on this work, M. Waters continued to study the components of media space and modified the classification of space-flows by J. Baudrillard's concept of simulacra [47]. N. Couldry and A. McCarthy note that media is material and consists of real objects (e.g., books, CDs, receivers and other transmitters of information) that are an integral part of particular power structures or segments of economy [13]. Thus, media space is primarily a dialectical concept reflecting the transformations of social space by various forms of media.

An alternative interpretation of the media can be found in the works of American scientists $[1 ; 18 ; 30]$ : they believe that true intentions (motives) of the media can be different than they appear to readers, viewers and listeners. Despite their heterogeneity, media are flexibly situated within networks that generate effects. These agglomerative networks of humans and non-humans both perpetuate old ways of doing things and contribute to the evolution of new ones - all in particular. Media practices, processes, and figures are deeply grounded in materiality and are themselves necessarily bound to material forms. As communicative objects (images, narratives, discourses, etc.) they are continually translated, recoded, and rematerialized through a variety of different physical forms. Even the invisible (to humans) transmission of signals through the electromagnetic spectrum is a wholly material process whereby materially existing signifiers (in semiotic terminology) circulate meanings across potentially vast distances and variegated cultural contexts. Although these networked communicative processes and practices are unavoidably rooted in materiality, the manner how they appear in our homes, workplaces, and public space often hides many aspects and motives $[1 ; 18 ; 30]$.

P. Adams with co-authors include in the notion of 'media space' not only the mass media but also fundamentally new types of communications such as blogs, social networks, websites, and all technical means of production, transmission, perception and consumption of information [1]. In the global media space supported by the Internet, each element represents a part of the whole and has the potential to interact with all other components of the global system. The global communication network includes various communication models; its structural elements interact not only within the model but also with elements of other subsystems of the World Wide Web. "Media and communications do not simply penetrate our places or ourselves. They (including the meanings they circulate) are negotiated and appropriated by us in places and ways that form a final layer in the constitution of a field of activity that some label the mediasphere. J. Hartley describes the mediasphere as something big enough to cover the planet, coherent enough that each tiny part may interact with all others, and small or local enough to affect every individual... It expresses various forms, relationships and structural conditions for existence and interaction of a worldwide system of media communication" [21].

According to P. Bourdieu, sociology is a social topology. Therefore, social world is a multidimensional space built on the principles of differentiation and distribution, formed by the combination of properties that can provide its owner with power and authority. Agents and groups of agents are defined by their relative positions in this 
space. Thus, media space implies both structural dependence of the local upon something that exceeds it and differentiation of particular locales from one another. Media space as a "structured social space, a field of forces" that contains "people who dominate and who are dominated" locked in "permanent relations of inequality", within which "various actors struggle for the transformation or preservation of the field" [8. P. 40].

In Russia, media space is defined as "a social space formed and saturated with information by the media" [40]. Media space is not a territory that can be visualized although social space covered by some media can be located within geographical or administrative boundaries. The very 'saturation' of media space is a special form of the results, means and forms of information received from the mass media. The structure of media space consists of the following elements: (a) mass media that constitute the material, physical basis for the production and transmission of mass information; (b) social relations of media agents within the production and consumption of mass information; (c) information symbolic product in which mass information is distributed. "Media space is a social system, therefore its structural elements (radio space, print space, Internet, etc.) are subject to general laws of the media development. Elements of this space differ in the degree of influence and scale but are all interconnected; changes in one element of the system affect all others" [42]. Thus, violation of ecology in any part of media space can lead to violations of its other components in the future.

"Today the concept 'media space' is used in both the Newtonian sense - as a kind of conditional territory on which information and its carriers are located and producers and consumers of mass information come from time to time; and in the Leibnizian sense - as a system of relations in the production, distribution, processing and consumption of mass information. However, the most important feature of media space is that the actions of all the above mentioned agents are determined by the norms and rules inherent in the social institution called media". Thus, media space appears either in the form of an information field within media system or in the form of an unreal information space, the agents of which are only information producer and its target audience. At the same time "media space should not be viewed as a kind of empty territory, a 'repository' of actors and communication processes, indifferent to what is happening in it; it is a complex self-organizing system that with the help of direct and reverse ties affects all processes within its boundaries and reacts to them" [14]. "The sociological structure of media space consists of four elements: media, audience, content and symbols" [11].

\section{ECOLOGY OF INFORMATION SPACE}

Today society faces challenges of the media space development and of protecting population from the negative impact of the media. Therefore, we need a system of legal and social guarantees that every citizen will be able to receive all necessary information and will be protected from the impact of the disturbed ecology of media space. However, not everyone within the sphere of intensive information coverage is aware of its negative consequences due to the fact that "first, information interactions are considered either insignificant or not having negative consequences. And, second, we believe that it is 
easy to counter the information impact (e.g. to turn off TV, leave the cinema or a concert, etc.). The media technology development shows that the impact of information processes can be considered similar to energy-related but exceeds them". Aggressive information environment deprives people of independent thinking, freedom of creativity, inspiring ideas, and distorts human cognition. These problems should be studied in the framework of 'information ecology' [4. P. 2-3].

"Information ecology is defined differently but we believe that this is a science that studies patterns of the information influence on the development and behaviour of a person, social communities and humanity as a whole, on individual and social relationships with the information environment, and also on interpersonal and intergroup information interactions" [48]. The goals and objectives of information ecology include all issues of human interaction with information environment. Media ecology is a section of information ecology for it studies human interaction not with the entire information environment but with media environment. Media ecology evaluates the state of media environment, possible impact of symbolic systems and technologies on the individual and human society as a whole.

It is believed that the term 'media ecology' was introduced by N. Postman in his speech at the National Congress of Teachers of English in 1968. He referred to the works of M. McLuhan who used the term 'media ecology' in his books The Guttenberg Galaxy (1962) and Understanding Media (1964). Media ecology questions the ways media affect human perception, understanding and feelings, and whether interaction with the media facilitates or complicates our survival [34. P. 160-168]. Media ecology affects various spheres of human life connected with information and communication. They include coding, data collection, processing, communication methods and theories; all procedures related to the development of content, systems and models of communication and information. Media ecology "is the study of media environments, the idea that technology and techniques, modes of information and codes of communication play a leading role in human affairs... It is technological determinism, hard and soft, and technological evolution. It is media logic, medium theory, mediology. It is McLuhan Studies, morality-literacy studies, American cultural studies. It is grammar and rhetoric, semiotics and systems theory, history and philosophy of technology. It is the postindustrial and the postmodern, and the preliterate and prehistoric" [44].

Media ecology develops as a metadiscipline that considers a complex system of interactions between media environment and a person and/or social communities. Media ecology experts study how the media, social technologies, techniques and methods of media influence affect human feelings, thoughts, values and behaviour. However, "media ecologists do not as yet have a coherent framework in which to organize their subject matter or their questions. Media ecology is, in short, a preparadigmatic science" [31]. In general, media ecology studies media environment of a man: its structure, content, methods, impact on people. Media environment is a complex system of information impact which provides people not only with different information but also with certain ways of thinking, perception of environment and behaviour. In some cases, mediators determine specific feelings and anticipated actions, i.e., in consulting (including remote 
communications) mediators specify what to do, assign an impact and insist on its implementation. "In the case of media environments (e.g., books, radio, film, television, etc.), the specifications are more often implicit and informal, half concealed by our assumption that what we are dealing with is not an environment but merely a machine. Media ecology tries to make these specifications explicit. It tries to find out what roles media force us to play, how media structure determines what we are seeing, why media make us feel and act as we do" [34].

Thus, there is a need for social adaptation of the person living and acting in the contemporary information environment. It is important not only to use information resources but also to develop an information worldview, propagate humanistic ideas, eliminate the discrepancy between the high-level technology development and low-level human culture. "At the same time, there is no doubt that media space, overloaded and 'clogged' with unnecessary and even dangerous information, poses a certain danger to individuals and organizations... And as in the case of nature management, in this situation opportunities go hand in hand with dangers. Protection of information ecology, a necessary condition for the present and future, is an urgent problem that can be addressed by legal regulation, the 'strongest' instrument of which is criminal law". There are "serious violations of media space. Aggression and violence have overflown the television. Such a state of affairs significantly worsens the social-psychological basis of public life, contributes to the atmosphere of uncertainty and instability and increases the feeling of being in constant danger. The most disastrous is the media impact on the younger generations that implement models of aggressive behaviour shown on television" [42. P. 40].

\section{VIOLATION OF MEDIA SPACE ECOLOGY}

A series of experiments [19. P. 115-142; 36. P. 69-80; 38. P. 397-406] proved that a mere observation of the model facilitates one's reactions to it in the given social setting. Thus, "the comparison of the behaviour in a generalized situation showed that participants representing the aggressive model prefer aggressive reactions corresponding to the model, and their average scores were significantly different from representatives of non-aggressive and control groups. Representatives of aggressive group also demonstrated partially imitating reactions and non-aggressive behaviour and usually had less control over their behaviour" [6. P. 575].

Some authors believe that the print media are less likely than the electronic ones to cause aggressive behaviour. The print media do not have audio-visual or visual elements, thus, do not activate the same immediate emotional perception as radio and television. N. Postman describes the dominant ideas and ways of thinking that are fostered by electronic communications as "dangerous nonsense"' [35] or a 'dangerous delirium': "we are becoming more stupid by every minute" [15. P. 24]. The today's mass media, especially electronic ones, have the ability to exert negative impact and media violence. Television violence is especially dangerous for the younger people. "Despite the growing concern about the mental health of children, TV programs with images of cruelty and violence are created at will of the general audience... Television 
is the first truly democratic culture - the first culture available to everybody and entirely governed by what the people want. The most terrifying thing is what people do want" [15]. Human civilization is increasingly engaged in a certain symbolic sphere generated by media, advertising, film and video products, the Internet, etc. It surrounds a man with images and symbols, takes him into the virtual world of artificial and false meanings. However, patterns and dangers of our interaction with the new information world are poorly understood though we admit that the personal world changes under the influence of the symbolic sphere and its negative psychological consequences including the loss of the true freedom of spiritual and moral self-determination.

Human intellect and its evolution depend on the nature of the information flows. The mass media, especially electronic media, are able to purposefully form certain mechanisms of mental activity with both qualitative and quantitative impact on the person's thinking. The so-called 'information anarchy' leads not only to moderate negative consequences but in some cases to 'information ecocide' - "destruction of traditional information and its carriers (messages, symbols, signals, signs, images, knowledge systems)" [48]. The features of information ecocide are as follows: anti-national and anti-ethnic - destruction of language, alphabet, worldview (faith, religion), customs and rituals; inter-regional and inter-group - destruction of the common information space, information links between territories, settlements, groups; unscientific - destruction of the existing system of knowledge, information storages; antihuman - destruction of universal principles, propaganda of violence, tyranny, chauvinism, violation of human rights.

We need to develop a new social technology to adapt to the contemporary information environment, which requires knowledge of how to use information and information resources, to create an information worldview consisting of the laws of information functioning in society, to understanding the essence of information transformations and one's place and tasks in the emerging information society [29].

To deter the pollution of the information environment we have to develop specific requirements to the creation of the content, control the collection, storage, processing and destruction of information, and develop criteria for assessing the use of information. 'Information hygiene' requires development and application of specific requirements and control over information flows. It is necessary to introduce a general rating system of information products, which will allow users to evaluate the quality of information sources. This, in turn, requires criteria for assessing information including its purity and filters, labour costs for creating the content, scale of coverage, quality (completeness of information), sources of data, and social-demographic characteristics of potential audience. The ecological quality of information is evaluated through its social character, linguistic criteria (criticism, volume, bias), and historical aspects. Thus, the checklist for successful counteraction to information pollution consist of (1) an information requirements plan; management and control over collection, storage and distribution of information; assessment of the use of information [4. P. 5; 23. P. 32-36].

The mass media have a great impact on human cognition and can purposefully form the point of view even if the recipient does not accept it. The position introduced through the media often becomes the dominant choice for human behaviour, i.e. there 
is a real threat of the public consciousness control, which is a dangerous psychological aspect of human interaction with the information environment. In the large-scale information wars, the public consciousness becomes an object of influence, control and manipulations. Information ecology experts name the following risk factors inherent in the system "human being - information environment": immaturity of individuals expressed in inability to consciously choose information; personal predisposition to conformism and imitation; readiness to accept manipulative information; negative functional state of the individual psyche; social situation contributing to increased anxiety or mass 'infection' with ideas and appeals of a charismatic personality [24. P. 134-137].

D. Lewis believes that the exponential growth of new information will soon be doubled every 20 months, which means that it will be necessary to constantly seek additional time to bring knowledge and skills in line with the demands of the time. Not so long ago, the knowledge acquired in the first 20 years of life was enough to make a living for the next 40 years; today the life span of knowledge is constantly shortened and after a certain period of time it does not have any 'market value'. For example, in the field of computation, application of the Moore law suggests that about half the knowledge of a specialist in this field becomes obsolete in several years. Moreover, "the information fatigue syndrome arises as a kind of psychological phenomenon leading to the adoption of erroneous decisions and incorrect conclusions" [24]. To prevent the information fatigue syndrome, Lewis suggests to (1) take advantage of every information technology used in business and daily communication, (2) improve methods of data collection and processing, (3) set correct priorities in the study of data [26].

\section{REFERENCES}

[1] Adams P.C. Tuanian geography: A tale of contrasts and nuances. Place, Space and Hermeneutics. Ed. by B. Janz. Springer; 2017.

[2] Adams P.C., Cupples J., Glynn K., Jansson A., Moores S. Communications/Media/Geographies. Routledge; 2017.

[3] Adams P.C., Jansson A. Communication geography: A bridge between disciplines. Communication Theory. 2012; 22 (3).

[4] Andreyko G.P. Ecology of Information Space. Kharkiv; 2015 (In Russ.).

[5] Appadurai A. Disjuncture and difference in the global cultural economy. Theory, Culture and Society. 1990; 7.

[6] Bandura A., Ross D., Ross S. Transmission of aggression through imitation of aggressive models. Abnormal and Social Psychology. 1961; 63 (3) (In Russ.).

[7] Beirne et al. Issues in Deploying the Technology for a Media Space. Toronto; 1994.

[8] Bourdieu P. On Television. New Press; 1998.

[9] Brinchuk M.M. Environmental law as a systemic phenomenon: Communication context. Communicology. 2015; 3 (1) (In Russ.).

[10] Buxton W. Space-Function Integration and Ubiquitous Media. Toronto; 2005.

[11] Buzin V.N. Social Management of Russian Media. System-Activity Approach. Moscow; 2012 (In Russ.).

[12] Christensen M., Jansson A. Cartographies of Change. Cosmopolitanism and the Media. Palgrave Macmillan; 2015. 
[13] Couldry N., McCarthy A. Orientations: mapping media space. Mediaspace: Place, Scale and Culture in a Media Age. Routledge; 2004.

[14] Dzyaloshinsky I.M. Contemporary Media Space of Russia. Moscow; 2015 (In Russ.).

[15] Elwell F.W. Neil Postman on the media \& sociocultural change. 2013. http://www.faculty.rsu.edu/ $\sim$ felwell/Theorists/Essays/Postman2.htm.

[16] Falkheimer J., Jansson A. Geographies of Communication: The Spatial Turn in Media Studies. Nordicom; 2006.

[17] Fuchs C. Culture and Economy in the Age of Social Media. Routlege; 2015.

[18] Glynn K., Cupples J. Negotiating and queering US hegemony in TV drama: Popular geopolitics and cultural studies. Gender, Place and Culture. 2015; 22 (2).

[19] Grosser D., Polansky N.A., Lippitt R.O. A laboratory study of behavioral contagion. Human Relations. 1951; 4.

[20] Harrison S. Media Space: 20+ Years of Mediated Life. Springer; 2009.

[21] Hartley J. Television Truths. Blackwell; 2008.

[22] Havelock E.A. Origins of Western Literacy. Toronto; 1971.

[23] Horton F.W. Information ecology. Journal of Systems Management. 1978; 29 (9).

[24] Kasyanov S., Aleshina L.I., Fedoseeva S.Y. Hygienic and physiological aspects of the information ecology. Facets of Knowledge. 2015; 8 (In Russ.).

[25] Kern R.L. Monkey Business. Cambridge; 2006.

[26] Lewis D. 10-Minute Time and Stress Management. How to Gain an 'Extra' 10 Hours a Week. Harper Collins Publishers; 1995.

[27] Mantei M. et al. Experiences in the Use of a Media Space. Toronto; 1991.

[28] McLuhan M., McLuhan E. Laws of Media: The New Science. Toronto; 1988.

[29] Mizintseva M.F., Koroleva L.M., Bondar V.V. Information Ecology. Moscow; 2000 (In Russ.).

[30] Moores S. Media, Place and Mobility. Palgrave Macmillan; 2012.

[31] Nystrom C. Towards a Science of Media Ecology: The Formulation of Integrated Conceptual Paradigms for the Study of Human Communication Systems. New York University; 1973.

[32] Patlasov O.Yu. Civilization pyramid transformation: From economy of consumption to social, cultural and environmental priorities. International Journal of Ecology and Statistics. 2017; $32(3)$.

[33] Patlasov O.Yu., Zharov E.K. Premises and environmental background for the transition to the creative development of economy. International Journal of Ecological Economics and Statistics. 2017; 38 (3).

[34] Postman N. The Reformed English Curriculum. High School 1980: The Shape of the Future in American Secondary Education. A.C. Eurich (Ed.). Pitman; 1970.

[35] Postman N. Amusing Ourselves to Death: Public Discourse in the Age of Show Business. Viking Penguin Inc.; 1984.

[36] Rosenblith J.F. Learning by imitation in kindergarten. Child Development. 1959; 30.

[37] Sawhney N., Maes P. Situational Awareness from Environmental Sounds. Project Report for Pattie Maes; 1997.

[38] Schacter S., Hall R. Group-derived restraints and audience persuasion. Human Relations. 1952; 5.

[39] Sharkov F.I. The transformation of society and nature in noosocietal system. Population. 2000; 4 (In Russ.).

[40] Sharkov F.I. Communicology. Moscow; 2009 (In Russ.).

[41] Sharkov F.I. Environmental monitoring as a means of social-environmental audit of local authorities. Protection of Environment as a Factor of Social-Economic Development of Municipalities: Practice and Problems. Rostov-on-Don; 2017 (In Russ.).

[42] Sharkov F.I., Yudina E.N. Regulation of relations in contemporary media space. Communicology. 2013; 1 (1) (In Russ.). 
[43] Springer S. et al. Leaky geopolitics: The ruptures and transgressions of WikiLeaks. Geopolitics. 2012: 17 (3).

[44] Strate L. Understanding MeA. Media Research. 1999; 1 (1).

[45] Stults R. Media Spaces. Xerox PARC; 1986.

[46] Tollmar K. et al. Video Cafe. Stockholm; 1999.

[47] Waters M. Globalization. Routledge; 1995.

[48] Yeremin A.L. Noogenesis and Theory of Intelligence. Krasnodar; 2005 (In Russ.).

[49] Yudina E.N. Media Space as a Cultural and Social System. Moscow; 2005.

DOI: 10.22363/2313-2272-2018-18-4-765-775

\title{
НАРУШЕНИЯ ИНФОРМАЦИОННОЙ ЭКОЛОГИИ В МЕДИАПРОСТРАНСТВЕ*
}

\author{
Ф.И. Шарков ${ }^{1,2}$, В.В. Силкин ${ }^{1}$, \\ И.Е. Абрамова ${ }^{3}$, Н.В. Кириллина ${ }^{1}$ \\ ${ }^{1}$ Российская академия народного хозяйства и государственной службы \\ при Президенте Российской Федерации \\ просп. Вернадского, 84, Москва, 119551, Россия \\ ${ }^{2}$ Московский государственный институт \\ международных отношений (университет) МИД России \\ просп. Вернадского, 76, Москва, 119454, Россия \\ ${ }^{3}$ Ростовский государственный медицинский университет \\ ул. М. Горького, 11/43, Ростов-на-Дону, 344002, Россия \\ (e-mail: sharkov_felix@mail.ru; vv.silkin@migsu.ru; \\ abramova-achii@mail.ru; nata.kirillina@gmail.com)
}

\begin{abstract}
Чрезвычайное «загрязнение» глобального информационного пространства негативно сказывается на социальном благополучии населения, поскольку медиапространство - разновидность социального пространства, охваченного медиа. Необходимо создать эффективную систему правовой защиты и социальных гарантий, чтобы любой гражданин мог не только получать минимальную социальную защиту, но и был защищен от негативного влияния неблагоприятной экологии средств массовой информации (СМИ). Не каждый, кто испытывает интенсивное воздействие СМИ, осознает его негативные последствия, в том числе «синдром усталости». Для его предотвращения Д. Льюис предлагает следующий алгоритм: воспользоваться всеми информационными технологиями бизнеса и повседневной коммуникации; усовершенствовать методы изучения и обработки данных; установить правильные приоритеты их анализа и использования [26]. Все СМИ и субъекты, находящиеся во взаимодействии с ними, должны овладеть информационной культурой, для чего необходимо готовить специалистов в области медиаэкологии, осознающих влияние медиа и социальных технологий на чувства, мысли, ценности и поведение людей. Пока специалисты по экологии СМИ не располагают достаточной теоретической базой для проведения социологических исследований и определения того, как медиа заставляют аудиторию структурировать то, что она видит, слышит и чувствует, определенным образом. Современные СМИ (особенно электронные) могут оказывать насильственное и нежелательное воздействие - это не только психологическая, но и философская,
\end{abstract}

* (C) Шарков Ф.И., Силкин В.В., Абрамова И.Е., Кириллина Н.В., 2018. Статья поступила в редакиию 30.04.2018 2. 
социальная и культурная проблема, которая затрагивает не только детей, но и взрослых. «Информационная анархия» приводит не только к умеренным негативным последствиям, но и в некоторых случаях к «информационному экоциду» - уничтожению традиционной информации и СМИ. Противодействие загрязнению информационной среды может включать следующие этапы: разработка требований к процессу создания контента; мониторинг процессов сбора, хранения, обработки и уничтожения информации; разработка критериев оценки использования информации. Необходимо ввести единую рейтинговую систему для информационных продуктов, которая позволит пользователям оценивать качество источников информации по следующим критериям: чистота информации; работа по созданию контента; охват источников; качество (полнота) информации; источники создания конкретных наборов данных; социально-демографические характеристики потенциальных пользователей.

Ключевые слова: окружающая среда; СМИ; медиа-пространство; медиа-социология; информационная экология; информационная гигиена; экоцид 